\title{
WORK WITH VIDEO DISPLAY TERMINALS AND REFRACTION ABNORMALITIES
}

\author{
Dimitrova T. ${ }^{1}$, Z. Zlatarova ${ }^{2}$ \\ ${ }^{1}$ Department Medico-biological sciences, ${ }^{2}$ Department of Neurosurgery, Otorhinolaryngology and \\ Ophthalmology, Medical University of Varna
}

Reviewed by: Assoc. Prof. E. Kontrova

\begin{abstract}
Working with video display terminals becomes more and more widely spread in the ever-changing world of labour.Aim: To study the ophthalmologic status in relation to the work conditions. The ophthalmological status was studied of 455 workers, divided in two groups: I group: 232 persons working half of their working time with video display terminals, with mean age of $42.08 \pm 0,8$ years; II group (control): 223 persons working without overload of the optical analyser, with mean age of $41.5 \pm 0.9$ years. Among those who passed a prophylactic ophthalmological examination, $168(36.9 \%)$ persons were without diagnosed deviations in the refraction (emetropes). In $77(21.8 \%)$ from the persons with deviations myopia was diagnosed, in $71(25.9 \%)$ it was hypermetropia, in $27(9.9 \%)$ it was astigmatism, and in 99 (36.1\%) presbyopia.Prolonged and continuous (without a physiological regime of work and rest) work with a video display terminal affects the vision sharpness.
\end{abstract}

Key words: video display, refraction abnormalities

Working with video display terminals becomes more and more widely spread in the ever-changing world of labour. Along with that, there also increase the closely connected with that kind of labour disorders of the optic analyser, back pains, muscular and joint disorders of the upper extremities, and neuroses. Research into the related to computerised labour problems of the vision and recognising the most susceptible to them people among the workers is a priority problem for medicine and ophthalmology.

\section{AIM}

To study the ophthalmological status in relation to the work conditions.

\section{MATERIALS AND METHODS}

Within the framework of the compulsory periodic prophylactic examinations the ophthalmological status was studied of 455 workers with mean age $41.77 \pm 0.62$ years, total length of service $20.46 \pm 0.6$ years, and specialised length of service $15.34 \pm 0.6$ years. A questionnaire was given on the working conditions, lifestyle and hereditary chronic diseases.

Address for correspondence:

T.Dimitrova, Dept. of Medico-biological sciences; Medical University - Varna; Varna, 9002, Marin Drinov Str., 55

e-mail: tvd@mnet.bg
I group: 232 persons working half of their working time with video display terminals, with mean age of $42.08 \pm 0,8$ years; II group (control): 223 persons working without overload of the optical analyser, with mean age of $41.5 \pm 0.9$ years.

\section{RESULTS}

After the ophthalmological examination those working with video display terminals and the control persons were divided according to the refraction into persons with myopia, hypermetropia, astigmatism, presbyopia and emetropia.

Among those who passed a prophylactic ophthalmological examination, 168 (36.9\%) persons were without diagnosed deviations in the refraction (emetropes).

In $77(21.8 \%)$ from the persons with deviations myopia was diagnosed, in $71(25.9 \%)$ it was hypermetropia, in 27 $(9.9 \%)$ it was astigmatism, and in $99(36.1 \%)$ presbyopia. In group I women prevailed: 183 persons or $78.9 \%$, in group II men prevailed: 144 persons or $64.6 \%$.

Refraction abnormalities were established in $65.5 \%$ of the persons who worked longer than half of the established by law work time with video display terminals, and in 54.7\% from the control group (Mann-Whitney U $23072 \mathrm{p}<0.05$ ). Similar results in relation to the higher frequency of refraction anomalies and neuroses among those working with video display terminals more than 2 hours every day were established by other authors as well $(1,2,10,11,12)$.

The most common cause for the weakening of the vision sharpness is short-sightedness and according to data from 
various authors it affects from 10 to $25 \%$ of the adult population in the world. Among the persons from group I myopia was statistically reliably established more frequently. Among them 55 persons or $23.7 \%$ needed correction of the myopic refraction against 22 or $9.9 \%$ from the control group (Mann-Whitney U $22287.5 \mathrm{p}<0.001$ ).

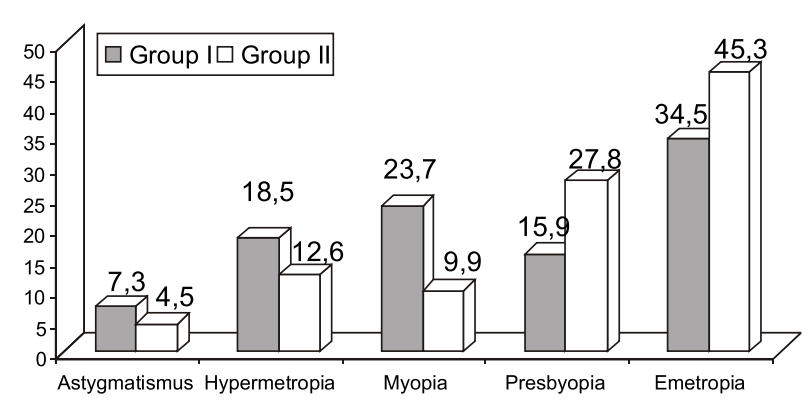

Fig. 1. Incidence of the diagnosed refraction anomalies according to their type (\%)

One of the main risk factors related to myopia is work that demands continuous fixation on small objects at a short distance. The chance to establish myopia among the persons in group I is 2.839 (CI95\%1.664-4.843 $\mathrm{p}<0.001)$ against those of group II. After standardising by age the probability increases to 3.121 (CI95\%1.796-5.423 $\mathrm{p}<0.001$ ), and after adjustment by length of service it reaches 3.885 (CI95\%2,003-7.536 $\mathrm{p}<0.001)$. Other authors also report on myopia of the vision after work with video display terminals. However, it is a matter of a reversible condition at the end of the working day (3).

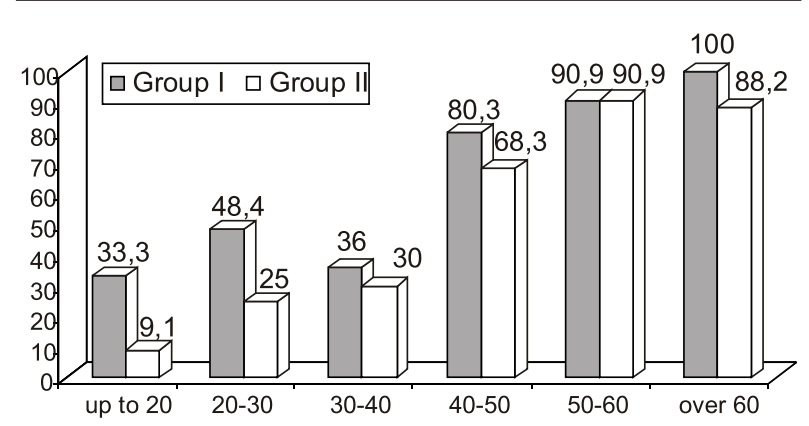

Fig. 2. Distribution of the affected persons according to their age (\%)

Work with video display terminals is associated with 1,573 (CI95\% 1.078-2.295 $\mathrm{p}<0.05$ ) risk of refraction abnormalities. After standardising by age the risk increases to 1.648 (CI95\% 1.029-2.642 $\mathrm{p}<0.05)$. And after taking into consideration the length of the specialised service the ratio of the chances reaches $1.813(\mathrm{C} 195 \% 1.042-3.152 \mathrm{p}<0.05)$ for refraction anomaly among those working with video display terminals as against those who do not use them.

When analysing the studied by age groups statistically reliable differences in the relative share of the persons with refraction anomalies in group I (48.4\%) and group II (25\%), such differences were established only in the group of 20 to 30 years of age $(\mathrm{p}<0.05)$. For that age $18(58.1 \%)$ of the persons working with video display terminals and 13 (25\%) of the persons working without them showed refraction anomaly (X square 4.752 Mann-Whitney U 617.5 $\mathrm{p}<0.05$ ). The ratio between the chances showed that among the persons we studied it is those between 20 and 30 years of age and working with video display terminals that are more in danger of refraction abnormalities with RR 4.154 (CI95\% 1.06-10.743 p<0.05). According to data from other authors the patient who most often complaints of computer vision syndrome is a 38-year-old woman with an average stage of short-sightedness who uses a monitor about 5 hours a day (6).

The specialised length of service that includes work with a video display terminal has a statistically reliable influence on the probability for the appearance of a refraction disorder in general and is not connected with just such disorder. According to our data, the professional length of service working with a video display terminal does not alter the risk for the appearance of myopia, for example. For the alteration in the vision sharpness, according to other authors, the weekly hours spent at the computer are accountable, and not the years in the length of service when computers were used, or the type of the work task performed $(7,9)$.

Stress at the workplace assessed subjectively by the persons who had a prophylactic examination on a scale from 1 to 10 also reliably affects the spread of myopia among the people in group I. Those who gave a 7 or more for the strain at work, myopia was diagnosed in $29(32.6 \%)$ of the examined against $12(18.8 \%)$ of the other persons from group I $(\mathrm{p}<0.05)$. Psycho-emotional strain is considered as a risk precipitating factor of the work task when working with a video display terminal by other authors as well $(4,5,10,11)$. Among persons in hypostress refraction anomaly was diagnosed in $14(77.8 \%)$ persons in group I as compared to 18 $(46.2 \%)$ from group II $(\mathrm{p}<0.05)$. Among those working in hyperstress conditions myopia was established in 29 (32.6\%) persons from group I as compared to $2(5.1 \%)$ persons from group II $(\mathrm{p}<0.001)$. Among those who worked without strain of the optical analyser the probability to establish disorder of the refraction was $4.083(\mathrm{Cl} 95 \% 1.139-14.644 \mathrm{p}<0.05)$ in hypostress and $8.942(\mathrm{CI} 95 \% 2.015-39.688 \mathrm{p}<0.01)$ in hyperstress. In persons who displayed eustress no differences were found out in the incidence of disorders in the vision sharpness between groups I and II.

The analysis of the deviations in the vision sharpness shows that in group II the abnormalities of the vision are without statistically reliable differences in the distribution between the two sexes. Seventy-two (50.0\%) of the men and 50 $(63.3 \%)$ of the women were affected $(p>0,05)$. In group I the ratio is similar but there prevail the groups of persons with refraction anomalies: $30(61.2 \%)$ of the men and 122 $(66.7 \%)$ of the women $(\mathrm{p}>0,05)$.

Men working with strain of their vision are older $(46.3 \pm 1.9$ years) than women ( $41.1 \pm 0.8$ years $\mathrm{p}<0.05$ ), while in the control group there is no reliable difference in the mean age of both sexes (men are with mean age of $40.9 \pm 1.2$ years, and women of $42.4 \pm 1.5$ years $\mathrm{p}>0,05$ ). In group I short-sightedness affects more often the women 52 (28.4\%) against $3(6.1 \%)$ in men $(p<0.001)$. 
Short-sightedness is established more often in women working with a video display terminal: $52(28.4 \%)$ from group I and $11(13.9 \%)$ from group II $(p<0.05)$. In men those who strain their optical analyzer more frequently show long-sightedness: 12 (24.5\%) from group I against 10 $(6.9 \%)$ from group II $(\mathrm{p}<0.001)$. According to the literature the female sex is considered to be more susceptible to showing vision fatigue when working with a video display terminal $(5,6,8)$.

Presbyopia is more common in women from the control group (24.1\% against $13.7 \%$ p 0.039$)$ although no difference is established between the mean ages of the women from group I ( $41.07 \pm 0.8$ years) against those from the control group ( $42.4 \pm 1.5$ years, $\mathrm{p}>0.05$ ).

The female sex is also the one more frequently affected by hypermetropia in the control group. It is $22.8 \%$ of women and only $6.9 \%$ of men not straining their vision during work that show long-sightedness $(\mathrm{p}<0.001)$.

\section{CONCLUSIONS}

Prolonged and continuous (without a physiological regime of work and rest) work with a video display terminal affects the vision sharpness.

The evaluation of the risk with reference to visual abnormalities when working with a video display terminal along with the length of the exposition should also include the subjective factors like sex and age of the exposed individuals.

A special approach is needed for the risk groups. Additional research needs to done to establish the target groups as well as the dynamics in the refraction in persons working with a video display terminal. Workers with refraction anomalies should be given appropriate working conditions for the use of a monitor: enough lighting, ergonomic work place, exact correction of the vision.

\section{REFERENCES}

1. Bartosinska M, Ejsmont J, Tukalska-Parszuto M., Morbidity among employees working with computers, Med Pr. 2001;52(3):185-95

2. Daum KM, Good G, Tijerina L., Symptoms in video display terminal operators and the presence of small refractive errors., J Am Optom Assoc. 1988

Sep;59(9):691-7.

3. Luberto F, Gobba F, Broglia A., Temporary myopia and subjective symptoms in video display terminal operators, Med Lav. 1989 Mar-Apr;

80(2):155-63.

4. Mocci F, Serra A, Corrias G A, Psychological factors and visual fatigue in working with video display terminals, Occup Environ Med 2001;58:267-271

5. Rocha LE, Debert-Ribeiro M., Working conditions, visual fatigue, and mental health among systems analysts in Sao Paulo, Brazil., Occup Environ Med. 2004 Jan;61(1):24-32

6. Salibello C, Nilsen E, Is there a typical VDT patient? A demographic analysis., J Am Optom Assoc. 1995 Aug;66(8):479-83.

7. Scullica L, Rechichi C., Is the type of VDT work important in asthenopia?, Eur J Ophthalmol. 1993 Jan-Mar;3(1):37-41.

8. Shima M, Nitta Y, Iwasaki A, Adachi M, Investigation of subjective symptoms among visual display terminal users and their affecting factors-analysis using log-linear models, Nippon Eiseigaku Zasshi. 1993 Feb;47(6):1032-40

9. Taino G, Ferrari M, Mestad IJ, Fabris F, Imbriani M., Asthenopia and work at video display terminals: study of 191 workers exposed to the risk by administration of a standardized questionnaire and ophthalmologic evaluation, G Ital Med Lav Ergon. 2006 Oct-Dec;28(4):487-97)

10. Tomei G, Rosati MV, Ciarrocca M, Capozzella A, Pimpinella B, Casale T, Monti C, Tomei F., Anxiety, musculoskeletal and visual disorders in video display terminal workers., Minerva Med. 2006 Dec;97(6):459-66.

11. Ustinaviciene R, Januskevicius V., Association between occupational asthenopia and psycho-physiological indicators of visual strain in workers using video display terminals., Med Sci Monit. 2006 Jul;12(7):CR296-301. Epub 2006 Jun 28

12. Ye Z, Abe Y, Kusano Y, Takamura N, Eida $\mathrm{K}$, Takemoto T, Aoyagi K., The influence of visual display terminal use on the physical and mental conditions of administrative staff in Japan., J Physiol Anthropol. 2007 Mar;26(2):69-73. 